\title{
Blue Swimming Crab Stock Assessment in the Western Visayan Sea
}

\author{
Sheryll V. Mesa ${ }^{1, \star}$, Drusila Esther E. Bayate ${ }^{2}$, May R. Guanco ${ }^{1}$ \\ ${ }^{1}$ Bureau of Fisheries and Aquatic Resources-National Stock Assessment Program, Regional Field Office 6, Iloilo City \\ ${ }^{2}$ Bureau of Fisheries and Aquatic Resources-Central Office, Diliman Quezon City
}

\section{A B S T R A C T}

Portunus pelagicus (Linnaeus, 1758) known as the blue swimming crab, ranks $4^{\text {th }}$ major fishery export of the Philippines. The Visayan Sea is considered as the major crab fishing ground of the country to which 25 out of $53 \mathrm{crab}$ picking stations are located in Region 6. The study was conducted in the year 2011 to 2012 in ten crab fishing municipalities of the Western Visayan Sea conducting catch and effort, reproductive biology, and biological sampling. Results showed that a decreasing CPUE is observed compared in 1995 at $0.34 \mathrm{~kg} /$ panel to $0.19 \mathrm{~kg} /$ panel in 2011 and $0.26 \mathrm{~kg} /$ panel in 2012, with 17 to 20 gillnet-panels per boat per day. Surplus production models showed that MSY at 13,150 MT and $\mathrm{f}_{\mathrm{MSY}}$ at 19,473 gillnet-panels of the Fox model is achieved prior to the year 1999. In 2011 and 2012, yield decreases as a setback of increasing fishing effort. Population parameters results showed growth overfishing where the $\mathrm{L}_{\infty}$ value obtained at $19.10 \mathrm{~cm}$ for this study was lower compared to 19.95 to $21.77 \mathrm{~cm}$ in previous studies. Computed E value at $0.68^{\text {year-1 }}$ is higher than the threshold at $\mathrm{E}=0.5^{\text {year-1 }}$ and at optimum $\mathrm{E}_{10}=0.56^{\text {year-1 }}$. Recruitment overfishing is also apparent from the size catches of major crab fishing gears to length at first maturity of $11.5 \mathrm{~cm}$. Bottomset gillnet catches premature sizes by $57 \%$, crab pot by $62 \%$, and otter trawl by $95 \%$. Seasonality of crab catching peaks in July and January coincides with the peak spawning in August and January, and recruitment in October and January.

*E-mail: smyl2428@gmail.com

Received: 27 May 2017

Accepted: 22 October 2017
Keywords: Portunus pelagicus, exploitation, length at first maturity, crab pot, crab bottomset gillnet

\section{IN T ROD UCT I O N}

\section{Stock profile}

$\boldsymbol{P}$ ortunus pelagicus (Linnaeus 1758) belongs to the order Decapoda referring to ten appendages, infraorder Brachyura or true crabs, and family Portunidae or swimming crabs. Their carapace varies from being transversely ovate to transversely hexagonal and sometimes circular, with the male $P$. pelagicus having distinctively blue markings and a triangular abdomen while the female has a dull green color and semicircular abdomen. Called the blue swimming crab, flower crab, manna crab, or sand crab, $P$. pelagicus is known in the dialects as kasag, alimasag, lambay, or masag.

They are widely distributed in shelf areas particularly along the nearshore at depths not exceeding $70 \mathrm{~m}$ (Ingles 1996) and mainly in traditionally demersal fishing grounds including San Miguel Bay, Tayabas Bay, Ragay Gulf, Malampaya Sound, Asid Gulf, Visayan Sea, Guimaras Strait, Panay Gulf, Carigara Bay, Bohol Sea, Panguil Bay, and Tawi-tawi (Ingles 2004). The Visayan Sea and Guimaras Strait hereto referred as Western Visayan Seas, are the major crabbing areas, containing 25 of the country's 53 picking stations in 2011 (Bayate 2011). The most common artisanal gear used in shallow water are crab pots, known as panggal, but crabbers also use bottom set gillnets, otter trawl, crab lift net or bintol, and push net.
Fishing gears used in catching crab includes artisanal gears operating in shallow areas. Crab pots, locally known as panggal, having a wide variety of materials used and design, is the most common gear operating in the country. Other crab fishing gears include the bottomset gillnet, crab lift net or bintol, baby trawl, and push net.

Fishing activity for $P$. pelagicus started as early as the 1950s. Ingles (2004) describe its fishery in phases: $1^{\text {st }}$ level plateau and $2^{\text {nd }}$ level plateau as shown in Figure 2.

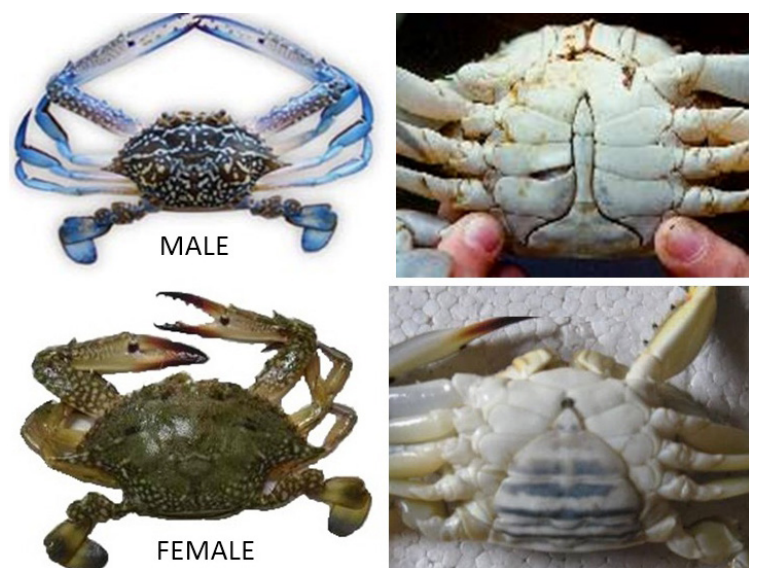

Figure 1. External difference between male and female Portunus pelagicus 


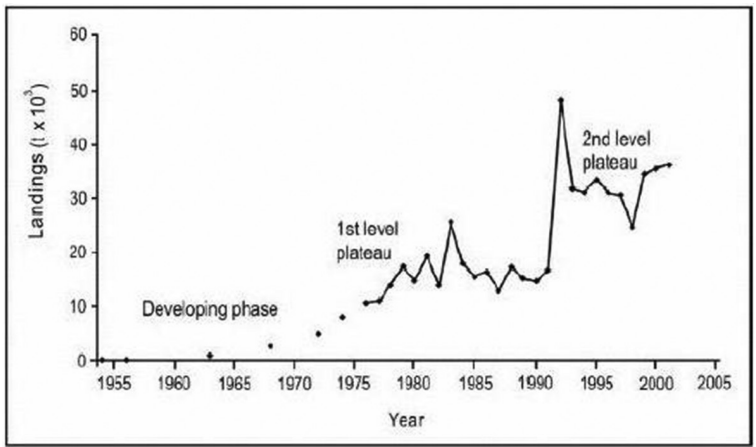

Figure 2. Historical production of blue crabs, Portunus pelagicus from year 1961 to 2005 (Ingles 2004)

The high demand for the blue swimming crab in 1990s is a result of the collapse of blue crab (Callinectes sapidus) in Chesapeake Bay, USA.

Data from the Bureau of Agricultural Statistics (BAS) shows that $P$. pelagicus ranks $4^{\text {th }}$ as a major fishery export in the country in terms of value at $\$ 67,612,600$ US as of CY 2010. The United States of America and neighboring Asian countries are the major country destination for $\mathrm{crab}$ and crab meat products export (Philippine Fisheries Profile 2010). The said fishery commodity is exported live, frozen, and prepared or preserved. According to the Food and Agriculture Organization (FAO), the blue swimming crab contributed to $0.19 \%$ of world production from the capture fisheries sector. Figure 3 shows the annual export trend in quantity and value of $P$. pelagicus in the Philippines for the year 1997 to 2012. The figure shows the $2^{\text {nd }}$ level plateau projected by Ingles $(2004)$ to which

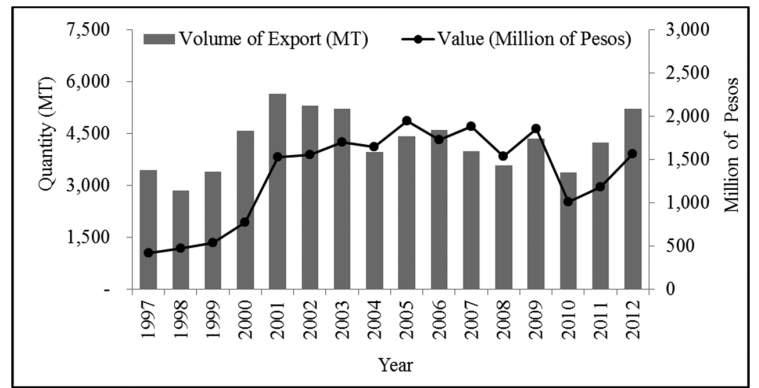

Figure 3. Annual trend in quantity (MT) and export value (millions of pesos) of crab exports in the Philippines for the year 1997 to 2012 (BAS, 1997-2012)

sources of crabs came from the artisanal fishing sector mainly using crab bottom set gillnet and crab pots. A clear indication shown in figure 3 is the law of supply and demand, less supply in terms of decreasing volume and an increasing demand shown by increasing market value.

P. pelagicus is considered as one of the major fishery resources of the country and has a high demand among the export industry (Ingles 2004). A huge percentage $(51.5 \%)$ of blue crab population comes from the Western Visayas (Visayan Sea \& Guimaras Strait) caught by gillnets, crab pots, trawlers, seines, and push net. History of the exploitation of crab resource was already determined in the early 90s. Because of the laxity in the implementation of regulatory policy to protect the resource, catch leveled off at around 1,000 mt but effort continued to increase, and in 1999 quadrupled to about 22,000 gillnet panels. This resulted in a significant reduction in catch rates.

\section{Major Crab Fishing Gears}

\section{Bottom set Gillnet/Crab Entangling Net}

The bottom set gillnet or the crab entangling net is a type of gillnet anchored and fixed on the sea floor. The gear is locally known as palubog, palugdang, or pukot. The net, as shown in figure 4 , is anchored and weighed down at the bottom so that it will not move with the water current (Green et al. 2004). The net is made of monofilament nylon material at $10 \mathrm{~cm}$ or 4 in mesh size. It is set at 0.8 to $1 \mathrm{~m}$ depth and at 100 to $150 \mathrm{~m}$ per net panel overlapped at $10 \mathrm{~m}$ on both sides with the other net panel. The total number panel used per operation is at an average of 17 , making the total length of the net at 1.7 to

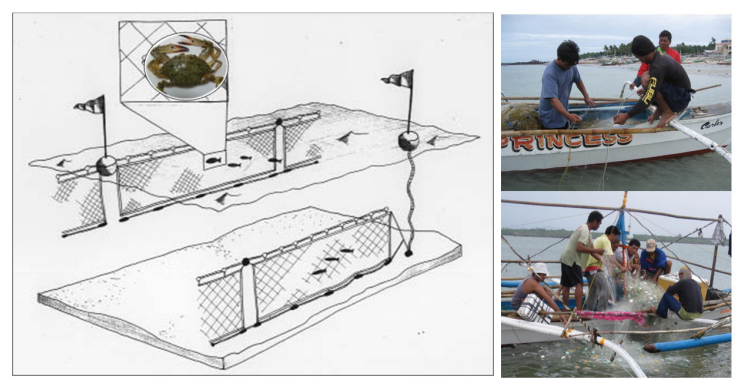

Figure 4. Mode of operation of drift gillnets (up) and bottomset gillnet (down). Bottomset gillnet is also the same gear used as crab entangling net (Bjordal 2002)

$2 \mathrm{~km}$. During operation, 1 to 3 fishermen are onboard the fishing boat during the net setting and hauling that takes around 13 hours soaking time.

\section{Crab Pot}

Crab pot is a type of trap gears (Figure 5) designed for catching crab species such as $P$. pelagicus, $P$. sanguinolentus, and Thalamita crenata. The gear is locally known as bubo pangasag, panggal, or timing. The gear is usually conical in shape and is of varied sizes and materials made depending on the area. Several designs of crab pots are employed in the Western Visayas depending on the area and are usually made of bamboo strips, polyethylene net, or synthetic chicken wires (Figure 6). The pot gear is usually soaked overnight, but longer soak times may be used in certain fisheries. The operation cycle is similar to that of longlining, with baiting, setting, fishing, and retrieval. The bait is either freely suspended in the middle of the pot, or put in perforated bait containers to prevent it from being eaten by scavengers (Bjordal 2002). During 


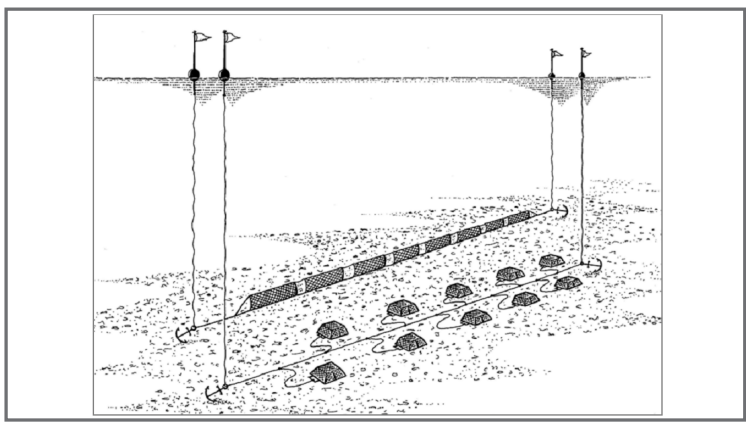

Figure 5. Setting of crab pot used in catching P. pelagicus in Western Visayas (Bjordal 2002)

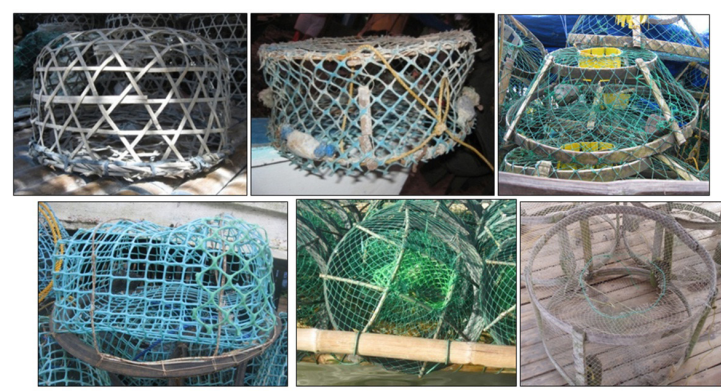

Figure 6. Designs and made of crab pots used in Western Visayas in catching crab species

operation, 1 to 2 fishermen are involved in pot hauling, setting, and bait replacement at 14 hours soaking time. In some areas, crab pots are set 24 hours and are only hauled the following day for catch hauling and bait replacement. Whereas in some areas where there are active gears such as Danish seine and otter trawls, the pots are hauled after 14 hours soaking time. Around 200 to 300 pots are used during operation set at a $5 \mathrm{~m}$ distance between pots.

Crab Trap

Traps are mostly box type in shape (Figure 7) and stationed in the water for a period of time regardless of materials used for construction. The target species are confined to a collecting unit from which escape is prevented by retarding device or funnel (SEAFDEC 1998). Crab traps are locally known as bubo pangasag and are commonly used in the areas of Northern Iloilo.

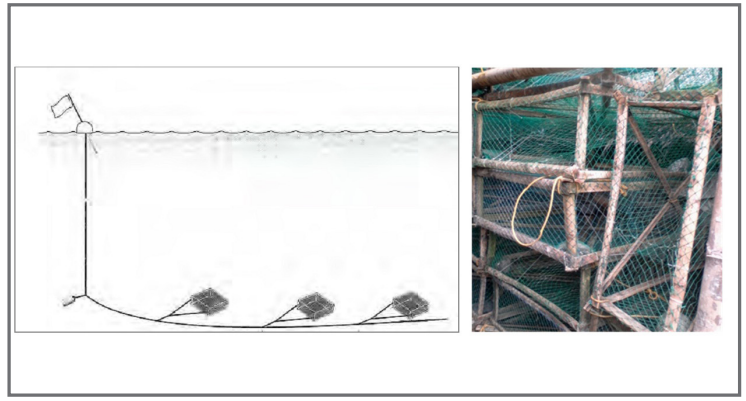

Figure 7. Setting of crab trap or fish trap at an interval of $5 \mathrm{~m}$ (left) and materials made of traps used in Western Visayas
Crab traps have the same catching mechanisms and are usually made of polyethylene or monofilament nylon with wooden brace forming the box shape. Upon operation, two or three fishers are involved in a 10-hour gear soaking time at an average of 100 traps per operation per day.

\section{Manual Push Net}

Manual push net (Figure 8) gear is normally operated to catch Acetes or hipon during the summer season. It is operated nearshore such that around $5 \%$ of immature crabs are also caught. It is a triangular-shaped net with a bamboo frame at both sides and unbraced at the base that filters the catches. The gear is locally known

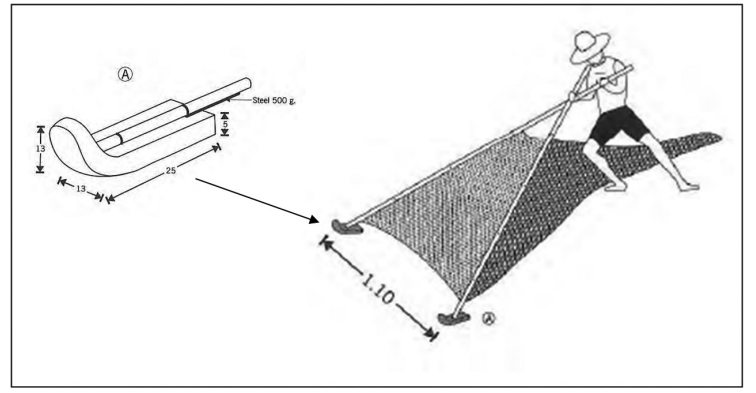

Figure 8. Mode of operation of manual pushnet used to catch Acetes and by-catch of $P$. pelagicus in the shallow waters of Western Visayas (Ruangsivakul et al. 2003)

as hud-hud if operated without the aid of a banca, and sungkit if operated using a motorized banca.The net is made up of knotless polyethylene at $63 \mu$ mesh size (Ruangsivakul et al. 2003).

\section{Otter Trawl}

Otter trawl (Figure 9) is a demersal type of trawl towed on the seabed, held open by a pair of otter boards or trawl door (SEAFISH 2005). Trawls are conical bagshaped net with two or more wings, pulled by one or two boats during dragging and catches mainly bottom living aquatic organisms (Ruangsivakul et al. 2003). Trawl has

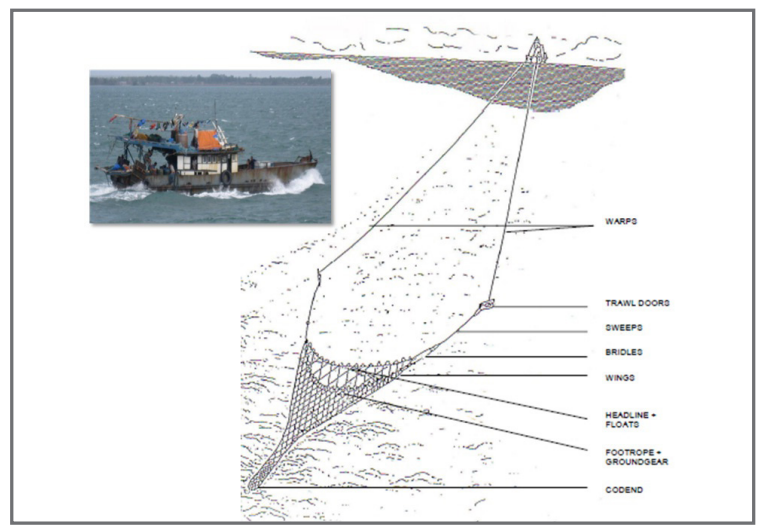

Figure 9. Parts of an otter trawl used to catch demersal organisms including by-catch of crab species (SEAFISH 2005) 
three types: pair, beam, and otter trawl. The Mid-water trawl is a trawl type modification where a mechanism of dragging is in mid-water catching mainly pelagic species.

\section{Legal Framework}

Section 98 of Republic Act (RA) 8550 or the Philippine Fisheries Code of 1998 states the prohibition on the catching of breeders or spawners of fishery species as may be determined by the Department of Agriculture (DA) thru the BFAR, provided that the catching of the breeders is for scientific or research purposes subject to appropriate guidelines set by the department. Joint DA-DILG Administrative Order (JAO) No. 01-2014 is a fishery regulatory adoption of the Philippine Blue Swimming Crab Management Plan (BSCMP). JAO 012014 enforces the registration of municipal crab fishers in their respective Local Government Units (LGU) to regulate the crab fishing activities. Also included is the prohibition of catching berried crabs: a minimum catch size of $10.2 \mathrm{~cm}$ carapace width, limit the mesh size of crab entangling net to $11 \mathrm{~cm}$, limit the number of pots per boat per day operation, limit the length of crab entangling net, and impose a closed season to municipalities with crab fishery.

RA 7160 or the Philippine Local Government Code of 1991 gives local autonomy to LGUs in managing their coastal resources. Article I section 16 of the RA 8550 states that the city/municipal government shall have jurisdiction over municipal waters as defined in the code (BFAR-FRMP 2000). With the autonomy of the LGUs and prior to the implementation of JAO No. 01-2014, local adoptions in the provinces of Negros Occidental and Iloilo are in place. In Negros Occidental, Provincial Ordinance No. 019 entitled "An ordinance regulating the catching, selling, possessing or buying of gravid blue crabs and crablets in the Province of Negros Occidental" is being implemented and was approved on September 2003 (Province of Negros Occidental 2003). Inclusions are: $11 \mathrm{~cm}$ carapace width size limit, $12 \mathrm{~cm}$ mesh size of gill net, and engaging in blue crab fishery without the required permit. In Iloilo, Provincial Ordinance No. 2012-093 prohibits the catching of berried and undersized crabs below $11 \mathrm{~cm}$, use of gillnet below $0.30 \mathrm{~mm}$ twine 4 knots and 50 mesh depth approved on February 22, 2012 (Province of Iloilo 2012).

\section{Review of Literature}

Blue crabs contributed $0.19 \%$ to world capture fisheries production in 2002. The collapse of the Callinectes sapidus fishery in the Chesapeake Bay, USA triggered a higher demand for Philippine blue crabs in the 1990s. In the Philippines, over $90 \%$ of the crabs landed are $P$. pelagicus which is the main species in the country's crab fishery since it started in the 1950s, with a developing phase, increasing to a 1 st level plateau in the 1980s, and a 2nd level plateau in the 1990s (Ingles 2004).

Studies on the crab fishery of the Philippines show the overexploitation of the resource. Maximum
Sustainable Yield (MSY) in the Visayan Sea was determined at 1,383 MT equivalent to an effort of 13,150 gillnet panels (Ingles 1996). As early as the 1990s, exploitation of the crab resource was observed to have leveled off at a low of 1,000 MT due to the absence of any regulatory policy to protect the resource, but effort continued to increase until it quadrupled to 22,000 gillnet panels in 1999 which resulted in significantly reduced catch rates (Ingles 2004).

In 2001, $P$. pelagicus ranked 5th in export volume at $560 \mathrm{MT}$ and 4 th in export receipts accounting for PHP 1.52 B (Ingles 2004). In 2010, it rose to become the 4 th major fishery product in the Philippines valued at US $\$ 67,612,600$ (BAS 2010) with the US and neighboring Asian countries as major product destinations. Despite fluctuating catch volumes, the increasing demand for blue crabs had pushed prices upwards over the years, generating higher export earnings. The Western Visayan Seas contribute some $51 \%$ of the blue crab catch using gillnets, crab pots, trawls, seines, and push net (Ingles 2004).

Romero in 2009 cored his study on the stock population analysis of $P$. pelagicus caught in the Visayan Sea. His significant result showed high exploitation status of the said resource at $0.94^{\text {year-1 }}$ ratio between E and E10. Another significant result is by comparing genetic stocks of $P$. pelagicus from various fishing grounds in the country and found four genetic stocks.

Williams and Primavera (2001) conducted a study in choosing of tropical Portunid species for culture as an alternative to Scylla for culture, domestication, and stock-enhancement in the Indo-Pacific. The study concluded that full domestication will not occur in the next 5 to 10 years and that the main constraints to be overcome are the aggressive behavior of the crabs, their carnivorous diet, and competition for suitable coastal farm sites. The study recommended that stock enhancement may be feasible in some locations, provided suitable fisheries management and industry institutions are created.

Several studies in other countries were also conducted for $P$. pelagicus in terms of its biology, behavior, culture, and stock enhancement. In terms of biology studies, it includes the embryonic development having a fecundity of 9 to 10 million of eggs at 6-7 days incubation period in India (Soundarapandian and Tamizhazhagan 2009). Fecundity for small-sized ( $8 \mathrm{~cm}$ carapace width) was at 78,000 and $1,000,000$ for large-sized (18 cm carapace width) in the West coast of Australia (De Lestang et al. 2003). In Bardawil Lagon, Egypt, length at first maturity obtained for a female was at $9.6 \mathrm{~cm}$ carapace width with the highest gonado-somatic index and peak spawning in the month of August (Razek et al. 2006). Spatial distribution of $P$. pelagicus in Trang Province, Thailand using collapsible crab trap showed that immature crabs were found in seagrass beds while large and ovigerous crabs were found in off-shore areas (Nitiratsuwan et al. 2010). In Karnataka Coast, India, observed spawning peaks in the months of January to February and September with spawning size at 10 to $16 \mathrm{~cm}$ 
carapace width. In Moreton Bay Australia, crabs attained sexual maturity during the first year and a rapid growth of juveniles in summer and autumn in inshore habitat, while growth slows during the winter season (Sumpton et al. 1994). The trap entrance behavior of crabs under laboratory condition showed a $25-30 \%$ success entry at a mean of 2 entrances per crab (Smith and Sumpton 1989). Bias in the capture of mature female crabs on traps compared to seining and trawling that are considered non-selective gears in Shark Bay, Australia (Smith et al. 2004). Chitin and chitosan content of the crab carapace and its potential as a biopolymer or gelling agent, food additive, and fish feed was also studied (Bolat et al. 2010; Sudhakar et al. 2009).

\section{Objectives}

This study aims to present current scientific information on the biology of Portunus pelagicus caught in the Western Visayan Sea to serve as baseline in the implementation of the proposed Blue Swimming Crab Management Plan:

a. Crab fishing gears inventory;

b. annual crab harvest estimates and catch per unit of effort ;

c. species relative abundance and monthly seasonality;

d. maximum sustainable yield;

e. reproductive biology (sex ratio, gonadal development, gonado-somatic index, length at first maturity, length ranges caught by different major crab fishing gears); and

f. population parameters (growth, recruitment, mortalities, probabilities of capture, relative yield and biomass per recruit).

\section{Scope and Limitation}

The Visayan Sea is a common fishing ground among its bordering regions 5, 6, and 7 . The implementation of this study is focused in Region 6 since it has the most number of crab unloading and picking stations among its neighboring regions. The outcome of this study will serve as an initial step in having a holistic approach by implementing the same activity with the major crabbing stations in regions 5 and 7 .

\section{MATERIALS AND METHODS}

\section{Study Site}

The Philippine shelf covers an area of 184,000 $\mathrm{km}^{2}$ to which $10,000 \mathrm{~km}^{2}$ or $5 \%$ is covered by the Visayan Sea. In terms of fish production, the Visayan Sea can produce three times its shelf capacity making it as one of the most important fishing grounds in the country. It is bounded on the north by Asid Gulf; on the east by Higantañgan Island; on the south by northern Cebu, Banatayan Island, and northern Negros Occidental;

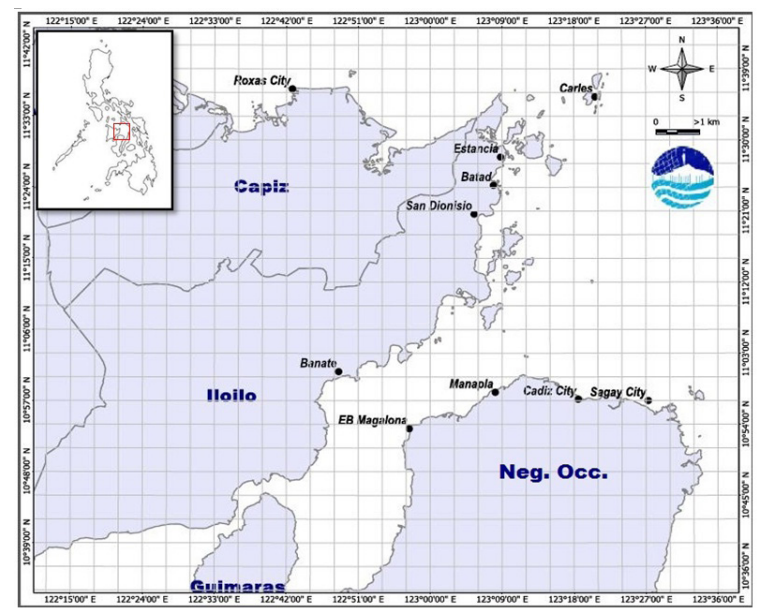

Figure 10. Map of Visayan Sea showing the BSC sampling stations and the areas that conducted the BSC reproductive biology study

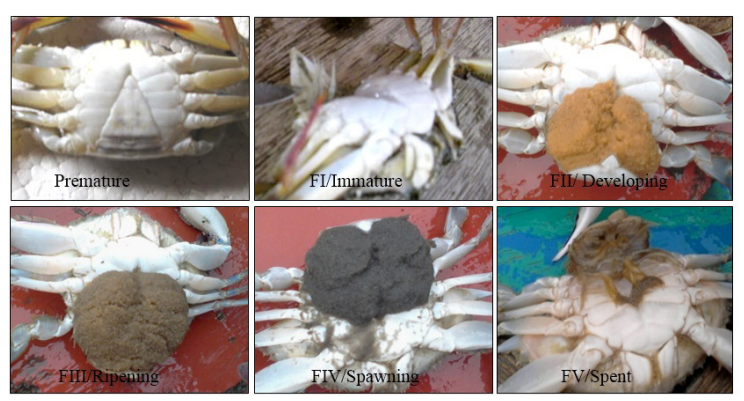

Figure 11. Five point scale used in determining the gonad stages of berried $P$. pelagicus

and on the west by Panay Island, Jintotolo Island, and Pulanduta Point of Masbate. It is located between 11 and $12^{\circ} \mathrm{N}$ latitude, 123 and $124^{\circ} \mathrm{E}$ longitude. Almost all of the towns bordering the Visayan Sea are fishing communities, the most important of which are DaanBantayan, Madridejos, and Bantayan of Cebu Province and Carles of Iloilo Province (Rasalan 1957).

Figure 11 shows the ten (10) sampling stations established in Western Visayas major crab unloading areas under the Blue Swimming Crab (BSC) Stock Assessment Project of the National Stock Assessment Program of the Bureau of Fisheries and Aquatic Resources- Regional Field Office 6 (BFAR-RFO6). Out of this, five crab landings of the stations were strategically selected to conduct reproductive biology sampling of $P$. pelagicus aside from the length based and catch and effort monitoring.

\section{Data Collection}

\section{Total Inventory}

The total fishing boat inventory and enumeration per fishing gear were based on the CY 2011 conducted in all Visayan Sea areas of the region. During the process of data collection, 56 enumerators were tapped to do the inventory data collection including admeasurements of 
Table 1. Five point scale of female gonadal maturity used for P. pelagicus (Sumpton et.al. 1994)

\begin{tabular}{|c|c|l|}
\hline Maturity Stages & Classification & \multicolumn{1}{c|}{ Distinguishing Characteristics } \\
\hline $\begin{array}{c}\text { Stage I } \\
\text { Stage II }\end{array}$ & $\begin{array}{c}\text { Immature/Virgin } \\
\text { Developing/Maturing }\end{array}$ & $\begin{array}{l}\text { Non-ovigerous } \\
\text { Ovigerous with pale to dark yellow egg mass. } \\
\text { No eyespots visible in eggs } \\
\text { Ovigerous with yellow-grey egg mass. Eye- } \\
\text { spots present. } \\
\text { Ovigerous with grey egg mass. Eyespots and } \\
\text { chromatophores discernible. }\end{array}$ \\
Stage V & Spawning/Gravid & Spent or Resting \\
\hline
\end{tabular}

the vessel, demographic profile of the respondents, and gear specifics as to materials made, mesh size, hook size, dimension of gears, baits used, and fishing operation information. Fishing boat enumeration of the commercial sector, on the other hand, was based on the monitored vessels in the sampling area; fishing vessel and gear registry of the Fisheries Resource Management Division of BFAR6.

\section{Catch and Effort}

Data collection for landed catch and effort schedule follows the national scheme of consecutive two sampling days. For months having 31 calendar days, total sampling days is 21 . For months with 30 days, the sampling frequency is 20 days. During each sampling day, the assigned field enumerator was tasked to know the name of the fishing boat, the corresponding fishing gear used, the fishing effort spent per day, the volume of catch, the species composition, and the length measurement of P. pelagicus.

\section{Reproductive Biology}

Sampling for reproductive biology was done on a weekly frequency per monitoring stations. A minimum of $5 \mathrm{~kg}$ samples per sampling day were collected, sorted per species, measured, and dissected. An average annual total of 3,488 specimens of $P$. pelagicus were collected and analyzed. Length measurement was done by determining individual carapace width $(\mathrm{CW})$ in centimeter $(\mathrm{cm})$ scale done by measuring from the tip of spines in both sides of the carapace. Individual weight was also recorded using the gram (g) unit. Dissection of the samples was done to identify the sex and the five-point scale (Sumpton et al. 1994) of gonadal maturity was used in the identification

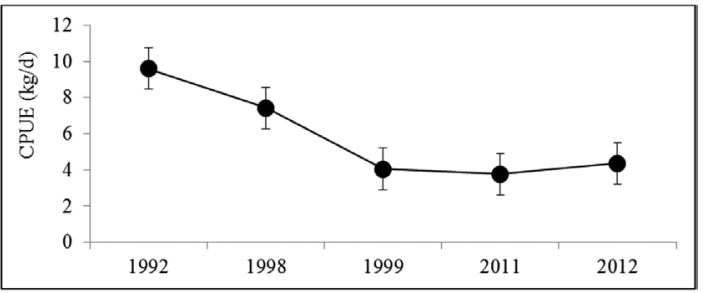

Figure 12. Annual cpue (kg/d) of crab gillnet in over three different years by Ingles (2004) and 2011 and 2012 of this study computed for Western Visayan Sea of female stages as described in Table 1 and Figure 12. Juvenile female samples identified with a semi-triangular ovarian flap were separated from mature samples. After which, the individual gonads were extracted for weighing and data were recorded using the gram unit.

\section{Data processing}

All data collected from the monitored sites were encoded on a spreadsheet in Microsoft Excel using a designed template. The templates were designed for data entry on catch and effort, fishing boat effort, length frequency, and reproductive biology. The template used for catch and effort and fishing boat effort allows us to do error tracking, editing, data reconciliation, sorting, and filtering which were all done using the pivot table routine in MS Excel. After all the data were reconciled, tables and graphs were generated to obtain indicators such as total fish harvest, catch per unit effort, species diversity, and seasonality of the major fish species. For the length measurement data, a separate template was created to do the daily raising and monthly merging of same species data. The generated annual raised data were encoded using the FAO-ICLARM Stock Assessment Tool (FiSAT) II version 1.2.2 (Windows) to obtain values for the population parameters. For the reproductive biology data sets, information generated include length at first maturity, monthly gonadal frequency, gonado-somatic index, and sex ratio.

\section{Fishing Days}

To generate information on fishing days, a separate fishing log sheet form was designed to record the fishing day's operation per fishing gear. The forms are marked on the days where vessels of a particular fishing gear unloaded, with or without catches as long as there is a fishing effort. The data collection is conducted either on a sampling or non-sampling days for catch and effort monitoring. The data collected were consolidated monthly by the field enumerators and annually by the data encoders. The said log sheet form becomes a major part of the monthly reports submitted by the field enumerators.

Catch per unit effort (CPUE)

The monthly catch per unit effort per gear was computed and standardized as kilograms per day (kg/ 
day). All data from the municipal sector having a per hour operation were converted into days. Annual mean CPUE was obtained by the summation of the monthly fish catch versus the summation of the number of fishing day operation per month, per year, and per gear.

\section{Crab Harvest Estimates}

Fish harvest estimates used standardized values by the direct relationship between catch per unit effort (CPUE), actual fishing days, and boat units based on inventory. The process was done per fishing gear per year.

\section{Relative Abundance and Seasonality}

Using the pivot table routine of the MS Excel, the 20 dominant species were ranked based on its percentage contribution to the total catch. The process was done by combined gears and by major fishing gears catching $P$. pelagicus. The factor used in the determination of seasonality distribution is the monthly catch (MT) of $P$. pelagicus analyzed for seasonality distribution using the monthly catch data from 2011 to 2012 .

\section{Potential Yield}

The objective of the application of "Surplus Production Models" is to determine the optimum level of effort that is the effort that produces the MSY that can be sustained without affecting the long-term productivity of the stock (Sparre and Venema 1992). It is used to refer to the surplus production that involves the Schaefer and Fox models that deal with estimates of surplus production of the entire stock, effort, and yield. The following equations were used for the computation as:

$$
\begin{gathered}
\text { Schaefer MSY }=-0.25^{\star} \mathrm{a}^{2} / \mathrm{b} \\
\text { Schaefer fMSY }=-0.5^{\star} \mathrm{a} / \mathrm{b} \\
\text { Fox MSY }=-(1 / \mathrm{b})^{\star} \operatorname{EXP}(\mathrm{a}-1) \\
\text { Fox fMSY }=-1 / \mathrm{b}
\end{gathered}
$$

where $a$ is the intercept and $b$ is the slope of the relative effort and relative yield for the Schaefer Model. For the Fox Model, $\mathrm{a}$ and $\mathrm{b}$ is the lognormal of the relative yield and relative effort.

\section{Reproductive Biology}

All data collected were encoded first on specified forms distributed to the enumerators to include information on landing center \& municipality source, month and date, weather and water condition, fishing gear source, scientific name, individual length, individual weight, sex, gonadal stage, weight of gonad, and actual fishing area based on the gridded map provided.

On the data encoding process, all information provided on the specified forms were included in a designed template using the Microsoft Excel format. After all of the data were reconciled, tables and graphs were generated to obtain indicators such as sex ratio, GSI, gonadal frequency, length at first maturity, length ranges, weather and water condition in reference to gonadal maturity. For the length measurement data, population parameters were obtained using the FAO-ICLARM Stock Assessment Tool (FiSAT II) version 1.2.2.

\section{$\underline{\text { Sex ratio }}$}

The sex ratios by month were expressed as the proportion of females to the total numbers of juvenile and male (Sheng-Ping et. al.2003):

$$
\text { Sex Ratio }=\mathrm{F}_{\mathrm{n}} / \mathrm{n}
$$

where $F_{n}$ is the monthly count of female and $n$ is the monthly total number of samples.

\section{Female gonadal frequency pattern}

Gonadal frequency pattern was tabulated using the count of juvenile and female per stages. These counts were converted to percentage for the relative frequency distribution per stages. Relative gonadal frequency distribution was done on a monthly and a weekly basis for analysis.

\section{Gonado-Somatic index (GSI)}

Gonado-Somatic Index (GSI) was calculated using the equation (İşmen, 2002):

$$
\text { GSI }=\text { GW/BW } \times 100
$$

where GW is the total wet weight of gonad and BW is the total wet body weight.

$\underline{\text { Gonadal classification in reference to seawater condition }}$

Gonadal stages were expressed in percentage (\%) and were related to seawater condition in every monitoring area. These data were plotted to see any correlation of gonad development over sea water condition.

\section{Length at First Maturity}

Length at which $50 \%$ of all individuals were sexually mature $(\mathrm{Lm})$ was estimated from the proportion of mature individuals in each of $5 \mathrm{~cm}$ length class interval and the fitted logistic curve (Sparre and Venema 1992) as follows:

$$
\mathrm{P}=\frac{1}{1+\exp (\mathrm{S} 1+\mathrm{S} 2 \times \mathrm{L})}
$$

where $\mathrm{P}$ is the proportion of mature individuals within a length class, S1 is the intercept, S2 is the slope, and $\mathrm{L}$ midpoint length. Corresponding weight at first maturity was also computed and fitted using the linear 
equation of $\mathrm{W}=\mathrm{aL}^{\mathrm{b}}$ where $\mathrm{W}$ is the estimated weight at first maturity, $a$ is the intercept, $b$ is the slope and $L$ is the computed length at first maturity.

\section{Length Ranges of crab gears}

Comparisons of length frequency distribution of same species caught by the different fishing gears were made to determine the type of fishing gear catching small size, bigger size, and wide range of size prior to the first maturity.

\section{Population parameters}

Data sets collected for reproductive biology were also those data sets used in the determination of seasonality changes. For purposes of discussion, data presented were consolidated to come up with oneyear data set. Data were then imported to FiSAT II for the generation of growth curve graphs. Information generated from FiSAT includes:

a. growth parameters (length at infinity $\left(\mathrm{L}_{\infty}\right)$, growth coefficient (k), and growth performance index (ø');

b. recruitment pattern (strong and weak pulse of recruit);

c. mortalities (total (Z), fishing (F), natural (M), and exploitation rate $(\mathrm{E}))$;

d. probabilities of capture $\left(\mathrm{L}_{25}, \mathrm{~L}_{50}, \mathrm{~L}_{75}\right)$; and

e. relative biomass and yield per recruit $\left(\mathrm{E}_{1}, \mathrm{E}_{\mathrm{max}}\right)$.

Growth parameters were determined first by estimating $\mathrm{L}_{\infty}$ (asymptotic length) using Powell-Wetherall method (Gayanilo et al. 1997) based on the equation of Beverton and Holt (1956):

$$
\mathrm{Z}=\mathrm{k}\left(\left(\mathrm{L}_{\infty}-\mathrm{L}\right) /\left(\mathrm{L}-\mathrm{L}^{\prime}\right)\right)
$$

where $\mathrm{Z}$ is the total instantaneous mortality, $\mathrm{k}$ is the growth coefficient, $\mathrm{L}$ is the mean length, $\mathrm{L} \infty$ is the asymptotic length, and L' is the initial length of the sample.

The estimated value of $\mathrm{L}_{\infty}$ was further processed in ELEFAN I (ELectronic LEngth Frequency ANalysis) for the verification of the value for Loo and $\mathrm{k}$. The analysis in the estimation of growth parameters and mortality uses the von Bertalanffy (1934) growth equation of:

$$
\mathrm{Lt}=\mathrm{L}_{\infty}\left(1-\mathrm{e}^{-\mathrm{k}(\mathrm{t}-\mathrm{to})}\right)
$$

where Lt is the length of fish at age $t, e$ is the of Naperian logarithm, and to is the hypothetical age the fish would attain at length zero.

Mortalities and exploitation rate were then calculated using the equation:

$$
\mathrm{Z}=\mathrm{M}+\mathrm{F}
$$

where $\mathrm{Z}$ is the instantaneous total mortality, $\mathrm{M}$ is the instantaneous natural mortality due to predation, aging, and other environmental causes, and $\mathrm{F}$ is the instantaneous fishing mortality caused by fishing.

Furthermore, $\mathrm{M}$ was estimated using Pauly's (1984) empirical formula:

$$
\log M=0.654 \log k-0.28 \log \mathrm{L} \infty+0.463 \log \mathrm{T}
$$

where $\mathrm{L}_{\infty}$ and $\mathrm{k}$ are the VBGF growth parameters and $\mathrm{T}$ is the annual mean habitat temperature $\left({ }^{\circ} \mathrm{C}\right)$ of the water in which the stock in question lives.

Expanding the equation for mortality would lead us to the computation of exploitation rate using:

$$
\mathrm{E}=\mathrm{F} / \mathrm{Z}
$$

where $\mathrm{E}$ is the exploitation rate. Using the equation from growth parameters and mortalities, prediction of recruitment patterns and virtual population analysis could be estimated using the routines found in FiSAT programs.

Recruitment patterns were obtained by backward projection onto the length axis of a set of length frequency data. The steps involved were:

a. projection onto the time axis of the frequencies after they have been divided by $\Delta t$, the time needed to grow through the length class, this leads to recruitment patterns with peaks much narrower than when untransformed length frequency data were used;

b. summation for each month (and irrespective of year) of the adjusted frequencies projected onto each month;

c. subtraction (from each monthly sum) of the lowest monthly sum to obtain zero value where apparent recruitment is lowest; and

d. output of monthly relative recruitment, in percent of annual recruitment.

Probabilities of capture involve the method of extrapolating the right descending left side of a catch curve such that fish that "ought" to have been caught were added to the curve with the ratio of those "expected" numbers to those that were actually caught being used to estimate the probabilities of capture. This can be computed as the ratio of the numbers observed over the numbers available $\left(\mathrm{N}_{\mathrm{i}}\right)$, using the equation:

$$
\mathrm{P}_{\mathrm{i}}=\ln \left(\mathrm{N}_{\mathrm{i}} / \Delta \mathrm{t}\right) / \ln \left(\mathrm{N}_{\mathrm{ai}} / \Delta \mathrm{t}\right)
$$

where $\mathrm{P}_{\mathrm{i}}$ refers to the points for probabilities of capture, $\mathrm{N}_{i}$ is the numbers of observed catch or the population size, and $\mathrm{N}_{\mathrm{ai}}$ is the numbers of available catch, and $\Delta \mathrm{t}$ is the change of time.

Beverton and Holt's (1957) relative yield per recruit and biomass per recruit models were used in the prediction of yield and standing biomass. Relative yield per recruit model is suitable for assessing the effect of mesh size regulations and it belongs to a length-based model as parameters. Biomass per recruit, on the other 
Table 2. Inventory of municipal fishing gears operating in the crabbing sites of Western Visayan Sea in year 2011

\begin{tabular}{|l|l|c|}
\hline \multicolumn{1}{|c|}{ Fishing Gear } & \multicolumn{1}{|c|}{ Common local name } & No. of units \\
\hline Bottomset gillnet & Palugdang, pukot, pukot-pangasag & 325 \\
Crab pot & Bubo pangasag, panggal, timing & 479 \\
Crab trap & Bubo pangasag & 36 \\
Modified danish seine (municipal) & Hulbot-hulbot & 131 \\
Fish coral & Punot & 195 \\
Filter net & Tangaban & 32 \\
Fish trap & Bubo & 49 \\
Manual push net & Hud-hod, sungkit & 21 \\
Otter trawl & Trawl & 111 \\
Surface-set gillnet & Pukot & 21 \\
\hline
\end{tabular}

Table 3. Annual CPUE, fishing days, and gear count of major crab fishing gears operating in Western Visayan Sea in year 2011

\begin{tabular}{|l|c|c|c|c|}
\hline \multicolumn{1}{|c|}{ Fishing gear } & $\begin{array}{c}\text { cpue } \\
(\mathbf{k g} / \mathbf{d})\end{array}$ & $\begin{array}{c}\text { Fishing } \\
\text { days }\end{array}$ & $\begin{array}{c}\text { Vessel count } \\
\text { by inventory }\end{array}$ & $\begin{array}{c}\text { Harvest } \\
(\mathbf{M T})\end{array}$ \\
\hline Bottomset gillnet & 3.26 & 248 & 325 & 262.92 \\
Crab pot & 4.61 & 246 & 479 & 542.93 \\
Crab trap & 4.00 & 229 & 36 & 32.94 \\
Modified danish seine (municipal) & 0.38 & 25 & 131 & 1.26 \\
Fish coral & 10.00 & 36 & 195 & 70.20 \\
Filter net & 3.08 & 4 & 32 & 0.39 \\
Fish trap & 0.83 & 8 & 49 & 0.33 \\
Manual push net & 16.89 & 70 & 21 & 24.83 \\
Otter trawl & 7.77 & 42 & 111 & 36.22 \\
Surface-set gillnet & 3.59 & 6 & 21 & 0.45 \\
\hline
\end{tabular}

hand, expresses the annual average biomass of survivors as a function of fishing mortality, and that average biomass is related to the catch per unit of effort. The said prediction models use the equations:

$$
\begin{gathered}
(\mathrm{Y} / \mathrm{R})^{\prime}=\mathrm{E}^{\star} \mathrm{U}^{\mathrm{M} / \mathrm{k}}\left(1-3 \mathrm{U} / 1+\mathrm{m}+3 \mathrm{U}^{2} / 1+2 \mathrm{~m}-\mathrm{U}^{3} / 1+3 \mathrm{~m}\right) \\
(\mathrm{B} / \mathrm{R})=\exp ^{\left(-\mathrm{M}^{*}(\mathrm{Tc}-\mathrm{Tr})\right) *} \mathrm{~W}_{\infty}{ }^{*}\left(1 / \mathrm{Z}-3 \mathrm{~S} / \mathrm{Z}+\mathrm{k}+3 \mathrm{~S}^{2} /\right. \\
\left.\mathrm{Z}+2 \mathrm{k}-\mathrm{S}^{3} / \mathrm{Z}+3 \mathrm{k}\right)
\end{gathered}
$$

where:

$$
\begin{array}{ccc}
\mathrm{m}=\frac{1-\mathrm{E}}{\mathrm{MK}}=\mathrm{k} / \mathrm{Z} & \mathrm{E}=\mathrm{F} / \mathrm{Z} & \begin{array}{c}
\mathrm{T}_{\mathrm{c}} \text { - Age at first } \\
\text { catch }
\end{array} \\
\mathrm{U}=1-\mathrm{L}_{\mathrm{c}} / \mathrm{L} \infty & \mathrm{T}_{\mathrm{r}}-\begin{array}{c}
\text { Age at first } \\
\text { recruit }
\end{array} & \begin{array}{c}
\mathrm{W}-\text { weight at } \\
\text { infinity }
\end{array}
\end{array}
$$
$\mathrm{T}_{c}$-Age at first catch

\section{RESULTSAND DISCUSSIONS}

\section{Crab Fishing Gears}

During the assessment period from 2011 to 2012, a total of 26 fishing gears are identified unloading in the study areas during the conduct of total fishing gear and boat inventory in 2011. Of the 26 total types of fishing gears, 11 are identified crab catching gears shown in table 2. Of the $11 \mathrm{crab}$ gears, bottom set gillnet, crab pot, crab trap, manual push net, and otter trawl are the major crab catching gears. By-catch of crabs are observed in the species catches of modified Danish seine, fish coral, filter net, and surface gillnet. Ingles (2004) during his study on blue swimming crab assessment also showed the same fishing gears catching crabs in Western Visayas. Illustrations and description of crab gears mode of operation are included in Figures 4 to 9.

\section{Annual Crab Harvest Estimates and CPUE}

Estimated fish harvest in the crab stations of the study is at 5,942.83 MT in 2011 and decreased at 2,967.61 MT in 2012. A significant decrease in crab harvest of 50\% is observed comparing 2011 and 2012. The significance is tested using the unpaired student t-test (Kaps and Lamberson 2004) at $\mathrm{P}=0.05$ which showed the $\mathrm{t}$-value obtained at 1.33 is lower than the critical value (v) at 1.645 on the hypothesis that fish harvest in 2012 is lower than the fish harvest in 2011. This may be correlated with the intensive monitoring, control and surveillance (MCS) of the BFAR-RFO6 in the implementation of Fisheries Administrative Order (FAO) 167 or the closed season of catching sardines mackerels and herrings in the Visayan Sea as the gears are also catching the prohibited species.

Tables 3 and 4 shows the annual crab harvest estimates per crab catching gears for the year 2011 and 2012 respectively. For the two years crab harvest, bottom set gillnet and crab pots are the dominant gears in terms of vessels count by inventory and fishing-days operation. Also observed is a high CPUE for fish coral and manual 
Table 4. Annual CPUE, fishing days, and gear count of major crab fishing gears operating in Western Visayan Sea in year 2012

\begin{tabular}{|l|c|c|c|c|}
\hline Fishing gear & $\begin{array}{c}\text { cpue } \\
\text { (kg/d) }\end{array}$ & $\begin{array}{c}\text { Fishing } \\
\text { days }\end{array}$ & $\begin{array}{c}\text { Vessel count } \\
\text { by inventory }\end{array}$ & $\begin{array}{c}\text { Harvest } \\
\text { (MT) }\end{array}$ \\
\hline Bottomset gillnet & 3.72 & 246 & 834 & 763.06 \\
Crab pot & 5.61 & 249 & 326 & 455.13 \\
Crab trap & 3.62 & 232 & 87 & 72.98 \\
Fish coral & 2.57 & 21 & 5 & 0.27 \\
Fish trap & 1.15 & 15 & 3 & 0.05 \\
Manual push net & 13.47 & 20 & 21 & 5.66 \\
Otter trawl & 2.09 & 101 & 27 & 5.70 \\
Surface-set gillnet & 1.25 & 29 & 21 & 0.76 \\
\hline
\end{tabular}

push nets, since the gear are seasonally operated and mainly operated for catching Acetes sp. during summer seasons in the months of March to May. These gears are also operated in shallow areas and are catching immature sized crabs (Ingles 1996).

Figure 13 shows the CPUE $(\mathrm{kg} / \mathrm{d})$ of crab gillnet over different years as included in the study of Ingles (2004) for the Visayan Sea in the year 1992, 1998, and 1999 , as well as the result obtained for this study in the year 2011 and 2012. A decreasing trend in the CPUE is observed that started at $9.61 \mathrm{~kg} / \mathrm{d}$ in 1992 to $4.05 \mathrm{~kg} / \mathrm{d}$ 1999 , at a mean annual decrease of $35 \%$. Comparing the result in 1999 as the last result of Ingles (2004) to this study, 7\% decrease in CPUE is observed comparing 1999 at $4.05 \mathrm{~kg} / \mathrm{d} /$ boat to 2011 at $3.76 \mathrm{~kg} /$ day. Comparing the CPUE of the year 1999 at $4.05 \mathrm{~kg} / \mathrm{d}$ to the year 2012 at $4.36 \mathrm{~kg} / \mathrm{d}$ showed an increase of $8 \%$. Based on this information, there is an increase in CPUE comparing the results of Ingles and this study.

Going to a much finer scale of analysis towards the trend of CPUE, Ingles (1996) also compared the catch rates using $\mathrm{kg} /$ panel/boat which is also adopted in this study. CPUE in 1991 was calculated at $0.62 \mathrm{~kg} / \mathrm{panel}$ at 10panels/boat to $0.34 \mathrm{~kg} / \mathrm{panel}$ at 19 panels/boat in 1995 with a mean annual decrease in CPUE of $14 \%$ but with increasing number of panels. Comparing again the last data of Ingles in 1995 which is $0.34 \mathrm{~kg} /$ panel at an average of 19 panels/boat with that of this study, a decreasing trend is observed as shown in Figure 14. The lowest CPUE is observed in 2011 at $0.19 \mathrm{~kg} / \mathrm{panel}$ at an average of 17 panels per boat and $0.26 \mathrm{~kg} /$ panel at 14 panels per boat in 2012 .

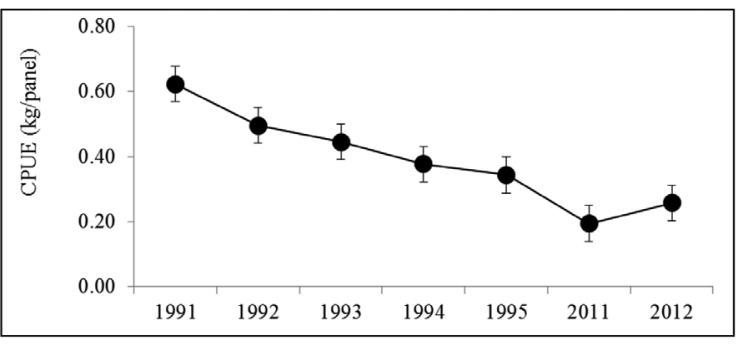

Figure 13. Annual cpue (kg/gillnet panel) of crab gillnet in over different years by Ingles (1998) and 2011 and 2012 of this study computed for Western Visayan Sea

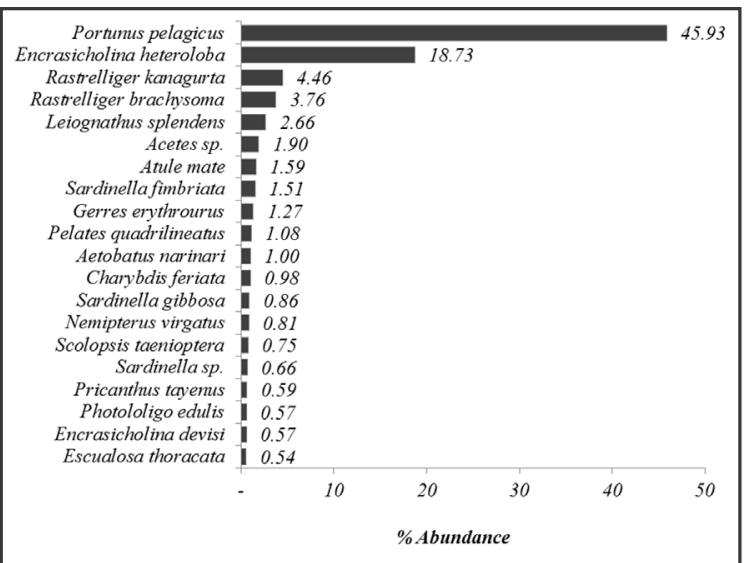

Figure 14. Relative abundance of the 20 major species in the crabbing areas of Western Visayan Sea during the conduct of Blue Swimming Crab Stock Assessment in year 2011 and 2012

Comparing the CPUE of crab gillnet as $\mathrm{kg} /$ day and $\mathrm{kg} /$ panel, we will be misguided if we just use the increasing CPUE using the $\mathrm{kg} /$ day catch rates. But on a more accurate basis, we may have expected an increase in CPUE in $\mathrm{kg} /$ panel if we assume it is homogenous with the $\mathrm{kg} /$ day. The least is that we may also assume that there should be an increase in CPUE since there was a decrease in the number of panels used in 1995 at 19 panels/boat to 17 and 14 panels/boat in 2011 and 2012. Despite the decrease in the number of panels used, CPUE in $\mathrm{kg} /$ panel still continues to decrease over the years.

\section{Species Relative Abundance and Seasonality}

Figure 15 shows the relative abundance of all species from all 26 fishing gears in the major crabbing areas of Western Visayas. Of the 224 species identified, 20 dominant species comprises $90 \%$ or $5,401 \mathrm{MT}$ of the total catch at 5, 993 MT. P. pelagicus comprises $46 \%$ of the total catches at 2,753 MT followed by Encrasiholina heteroloba at $18.73 \%$ or 1,122 MT. These two species already comprises the $65 \%$ bulk of catch and the remaining 35\% is composed of the 222 species.

Table 5 to 9 shows the dominant species and relative abundance of the major crab gears operating in the area during the conduct of the study. For bottom set gillnet in Table 5, 10 dominant species accounted for 
Table 5. Ten (10) dominant species identified for bottomset gillnet operating in the crabbing areas of Western Visayan Sea for the year 2011-2012

\begin{tabular}{|l|l|c|}
\hline Scientific name & Local Name & $\%$ \\
\hline Portunus pelagicus & Kasag;Alimasag & 51.11 \\
Rastrelliger kanagurta & Bulaw/Alumahan & 9.52 \\
Rastrelliger brachysoma & Hasa-hasa & 8.01 \\
Encrasicholina heteroloba & Dilis & 6.13 \\
Leiognathus splendens & Latab/Sap-sap & 3.64 \\
Atule mate & Bagudlong/kalapato & 3.39 \\
Gerres erythrourus & Latab/Malakapas & 2.69 \\
Aetobatus narinari & Pagi & 2.14 \\
Pelates quadrilineatus & Bugaong/Baga-ong & 1.81 \\
Priacanthus tayenus & Bukaw-bukaw/Siga & 1.24 \\
Others & & 10.33 \\
\hline
\end{tabular}

Table 6. Dominant species identified for crab pot operating in the crabbing areas of Western Visayan Sea for the year 2011-2012

\begin{tabular}{|l|l|c|}
\hline Crab Pot & Local Name & $\%$ \\
\hline Portunus pelagicus & Kasag/Alimasag & 93.49 \\
Charybdis feriata & Kurusan & 3.27 \\
Portunus sanguino- & Pintokan/Alimasag & 2.11 \\
lentus & & \\
Podopthalmus vigil & Instisk-intsik/Ali- & 1.09 \\
& masag & \\
Thalamita crenata & Dawat & 0.03 \\
Scylla serrata & Alimango & 0.01 \\
\hline
\end{tabular}

Table 7. Ten (10) dominant species identified for crab trap operating in the crabbing areas of Western Visayan Sea for the year 2011-2012

\begin{tabular}{|l|l|c|}
\hline Crab Trap & Local Name & $\%$ \\
\hline Portunus pelagicus & Kasag/Alimasag & 87.37 \\
Charybdis feriata & Kurusan & 6.62 \\
Scolopsis taenioptera & Opos-opos/Bisugo & 3.47 \\
Pelates quadrilineatus & Bugaong/Baga-ong & 2.09 \\
Portunus sanguinolentus & Pintokan/Alimasag & 0.15 \\
Opichthus altipennis & Igat/Palos/Ubod & 0.09 \\
Nemipterus bathybius & Bisguo & 0.08 \\
Upeneus sp. & Salmonete/Saram- & 0.07 \\
Selar boops & ulyete & \\
Paraplotosus albilabris & Mat-an/Matang-ba- & 0.03 \\
Others & ka & \\
& Ito & 0.02 \\
\hline
\end{tabular}

$89.67 \%$ where $P$. pelagicus accounts for $51.11 \%$ of the total gear catch. Table 6 for crab pot shows that the gear's catch is mainly composed of crab species with $93.49 \% P$. pelagicus, followed by Charybdis feriata at $3.27 \%$, Portunus sanguinolentus at $2.11 \%$, Podopthalmus vigil at $1.09 \%$, Thalamita crenata at $0.03 \%$, and Scylla serrata at $0.01 \%$. Crab pot is designed primarily for catching $P$. pelagicus while some other species are by-catch. The efficiency of crab pots relies mainly on its design where the region around six (6) designs are being used. For crab trap, top
Table 8. Ten (10) dominant species identified for manual push net operating in the crabbing areas of

Western Visayan Sea for the year 2011-2012

\begin{tabular}{|l|l|c|}
\hline Manual-Push net & Local Name & $\%$ \\
\hline Acetes sp. & Hipon & 95.71 \\
Portunus pelagicus & Kasag/Alimasag & 3.57 \\
Portunus sanguinolentus & Pintokan/Alimasag & 0.17 \\
Cynoglossus robustus & Palad/Dapang & 0.16 \\
& tsinelas & \\
Secutor ruconius & Palid/Waling & 0.13 \\
Cynoglossus abbreviatus & Palad/Dapang & 0.07 \\
& tsinelas & \\
Pennahia macrophthal- & Abu/Alakaak & 0.07 \\
mus & & \\
Plotosus lineatus & Hito/Ito & 0.03 \\
Sillago japonica & Asoos/Asohos & 0.03 \\
Eleutheronema tetradac- & Kugaw/Mamale & 0.02 \\
tylum & & \\
Others & \multicolumn{2}{|l}{} \\
\hline
\end{tabular}

Table 9. Ten (10) dominant species identified for otter trawl operating in the crabbing areas of Western Visayan Sea for the year 2011-2012

\begin{tabular}{|l|l|c|}
\hline Otter Trawl & Local Name & $\%$ \\
\hline $\begin{array}{l}\text { Platycephalus endracht- } \\
\text { ensis }\end{array}$ & Sunugan & 12.13 \\
Apogon aureus & Moong/Parangan & 9.20 \\
Fistularia commersonii & Stickfish/Trompeta & 7.35 \\
Paraplagusia blochii & Palad/Dapang & 6.66 \\
& tsinelas & \\
Photololigo edulis & Lokos/Pusit & 6.11 \\
Penaeus latisulcatus & Pasayan/Hipon & 5.35 \\
Metapenaeus palmensis & Pasayan/Hipon & 4.22 \\
Sepia lycidas & Bagulan & 4.11 \\
Penaeus merguiensis & Pasayan/Hipon & 3.59 \\
Portunus pelagicus & Kasag/Alimasag & 2.09 \\
Others & & 39.19 \\
\hline
\end{tabular}

2 dominant species comprising the bulk of catch by $94 \%$ includes P. pelagicus at $87.37 \%$ and C. feriata at $6.62 \%$ of the total gear's catch. Fish species, then, are considered as its by-catch.

Other crab catching gears such as the manual push net and otter trawl caught $P$. pelagicus and other crab species as by-catch. Manual push nets are mainly operated for catching Acetes sp. (95.71\%), P. pelagicus (3.57\%) and $P$. sanguinolentus $(0.17 \%)$ as part of the by-catch. For otter trawl, P. pelagicus comprises only $2.09 \%$ while the bulk of the catch is shrimps and other demersal fish species.

\section{Monthly Catch Seasonality of $P$. pelagicus}

Figure 16 shows the monthly catch seasonality of $P$. pelagicus caught in the Western Visayan Sea for the year 2011 and 2012. In 2011, catches peak in the month of October during peak harvest season and in January during the lean season. In 2012, a prominent peak season is observed in the month of May as its peak harvest season and also January during the lean season. 
Table 10. Computed sex ratio of premature, female, and male P. pelagicus caught in

Western Visayan Sea as observed in the conduct of reproductive biology study

\begin{tabular}{|c|c|c|c|c|c|}
\hline Species & $\mathbf{N}$ & Premature & Female & Male & $\begin{array}{c}\text { Ratio Premature: } \\
\text { Female:Male }\end{array}$ \\
\hline P. pelagicus & 3,487 & 223 & 1,595 & 1,669 & $1: 7: 7$ \\
\hline
\end{tabular}

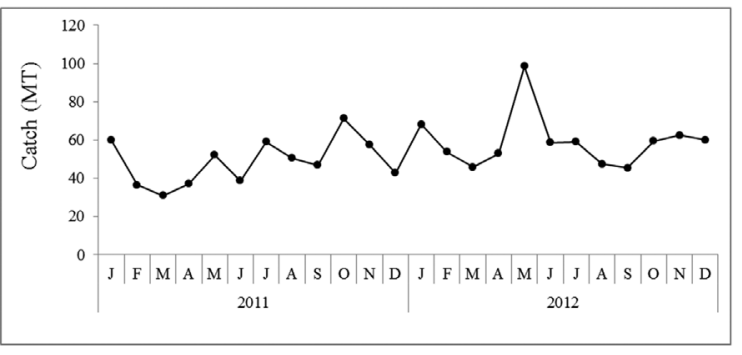

Figure 15. Observed monthly catch seasonality of $P$. pelagicus in Western Visayan Sea for the year 2011 to 2012

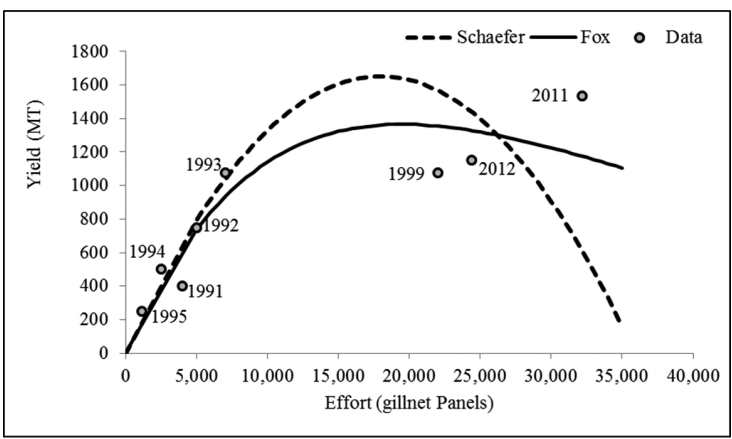

Figure 16. Estimates of the maximum sustainable yield (MSY) and maximum sustainable effort (fMSY) for the crab fishery of Western Visayas at different period using the Schaeffer and Fox Models

\section{Maximum Sustainable Yield}

Ingles (1996) has computed the maximum sustainable yield of $P$. pelagicus in Western Visayas using crab gillnet panels as a unit of measurement for the effort. This study also adopted the method in order to give a time series of information and determine the latest status of the crab gillnet fishery of Western Visayas as shown in Figure 17. In the study of Ingles (1996), the estimated MSY is at 1,300 MT at 13,150 gillnet-panels.

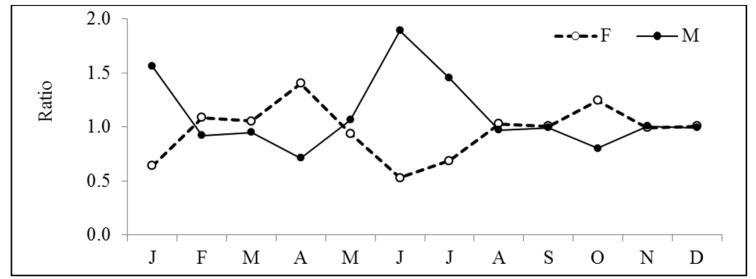

Figure 17. Observed monthly trend of sex ratio between male and female $P$. pelagicus caught in Western Visayan Sea
In this study, MSY is adjusted to $1,365 \mathrm{MT}$ at 19,473 gillnet-panel fMSY using the Fox model and to $1,652 \mathrm{MT}$ at $17,944 \mathrm{fMSY}$ using the Schaeffer model. Ingles (2004) added its data information in 1999 and showed that MSY and fMSY were achieved in 1993 where the effort in 1999 of 22,000 gillnet-panels quadrupled to its limit. Adding the information collected in 2011 and 2012 of this study showed that fMSY is also achieved prior to 1999 and the yield continues to decline due to the high fishing effort in gillnet-panels over the years. Results also showed that the increase in effort leads to the reduction by $20 \%$ in order to achieve MSY and fMSY. The increase in gillnet-panels in 2012 is attributed to the increase in the crab gillnet vessels operating in the area as shown in the total gear inventory. This then attributed to continued high fishing intensity towards the crab stocks in Western Visayas.

\section{Reproductive Biology}

Sex ratio

Table 10 shows the total number of samples collected per sexes of $P$. pelagicus used in the conduct of the study. As indicated in the table, a very low percentage of the premature samples were obtained. As observed in the sampling areas, small sized samples are caught by push nets and are caught together with Acetes sp. and form as part of by-catch. If we consider only the male and female sample population, a 1:1 ratio is obtained.

As shown in Figure 18, an inverse dominance of female and male sample population is observed. The high female ratio is observed in the month of April which is also observed lowest for the male. The month of June is observed peak for the male population while lowest for the female.

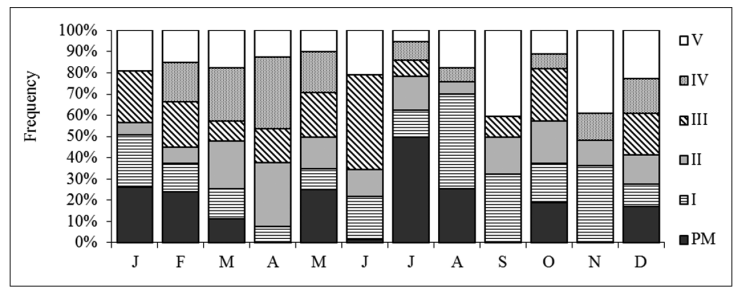

Figure 18. Monthly gonadal frequency distribution in percent obtained for $P$. pelagicus caught in Western Visayan Sea 
Female gonadal frequency pattern

P. pelagicus is observed to have continuous spawning year-round characterized by two spawning peaks (Ingles and Braum 1989). December to February is the observed peak spawning season (Ingles 1996) in the Philippines. Spawning season in neighboring countries like Australia is identified in the months of June and July (Svane and Hooper 2004); March to May in Karnataka Coast, India (Sokumaran and Neelakantan 1999); and March to April and August to September in Trang Province, Thailand (Nitiratsuwan et.al. 2010). Figure 19 shows the monthly gonadal distribution of premature and female $P$. pelagicus. As the figure suggests, a high percentage of non-ovigerous stages occurs in the months of July to February. Critical stage FV is present yearround with peaks in the months of September to January. Premature and FI stage is observed in the months of July to August and December to March. For the ovigerous or egg-bearing stages represented by FII, FIII, and FIV, peak months occur in the months of March to May.

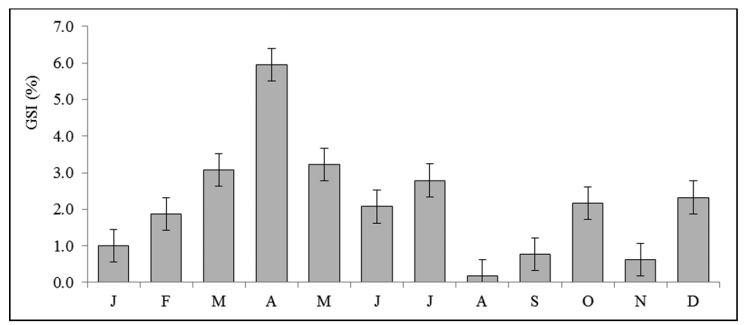

Figure 19. Monthly fluctuation of gonado-somatic index (GSI) observed for P. pelagicus caught in Western Visayan Sea

Gonado-somatic index (GSI)

Figure 20 shows the monthly fluctuations of GSI and the corresponding standard deviation obtained for $P$. pelagicus. As the figure suggests, the highest GSI is observed in the month of April with the dominance of FII, FIII, and FIV as shown in the gonadal frequency distribution. On the other hand, August has the lowest observed GSI with the dominance of premature FI and FV stages or the non-ovigerous stages.

Gonadal classification in reference to seawater condition

P. pelagicus occurs in a wide range of algal and seagrass habitats and on both sandy and muddy substrate (Svane and Hooper 2004). It undertakes active foraging using the tidal movements and moves to deeper areas as it increases in size (Ingles 1996). Sumpton et. al. (1994) associates $P$. pelagicus sex-aggregation with habitat preference. Female tends to migrate and burry in deeper and stiller areas for egg incubation and extrusion.

For this study, clear water condition is associated with deeper water areas on a fair weather and murky

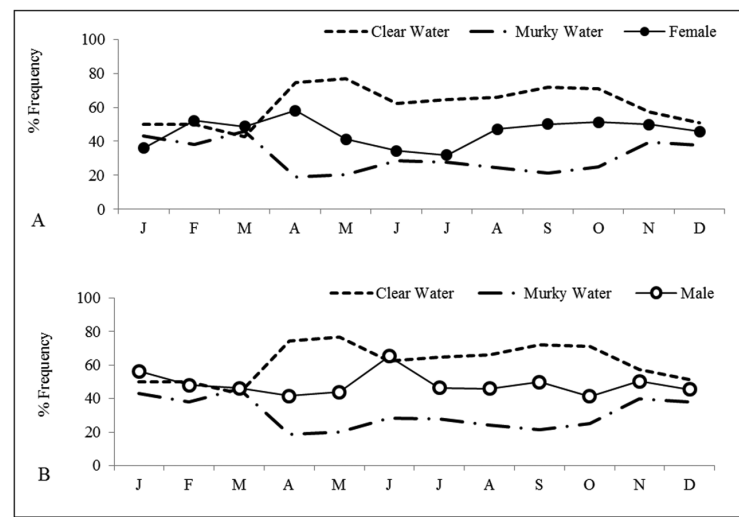

Figure 20. Monthly correlation observed between female (A) and male (B) $P$. pelagicus in relation to clear and murky water condition in Western Visayan Sea

water condition is associated with shallow areas with rainy weather condition. As discussed earlier on sex ratio, a reverse dominance of male to female population is observed which also holds the same for the seawater condition. Associating the two results as shown in Figure 21 , the dominance of female population is observed during the peak of clear water condition whereby crab gear operations are concentrated in deeper areas. Months of March to April are the observed peak of clear water condition that falls during the summer season. Associating it further on the gonadal frequency, months of March to April is the peak season for ovigerous females and which can be correlated with the egg incubation period. On the other hand, the male population is observed to coincide with murky water condition with the operation of crab gears in shallow areas.

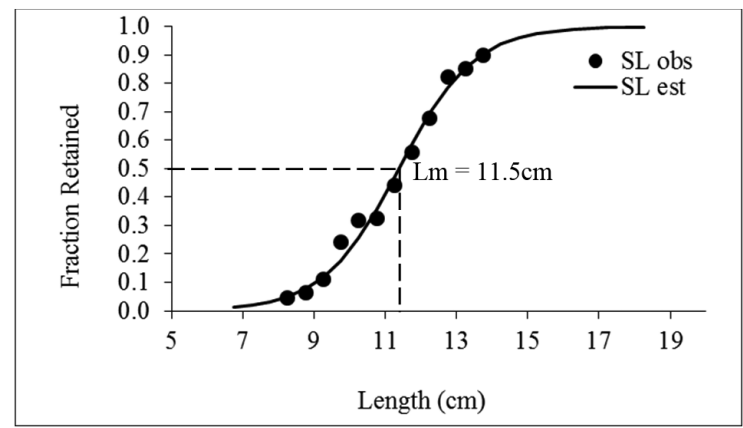

Figure 21. Observed length at first maturity $(\mathrm{Lm})$ for Portunus pelagicus caught in Western Visayan Sea

\section{Length at first maturity}

Following the logistic curve as shown in Figure 22 , the computed length at first maturity for P. pelagicus in this study is at $11.5 \mathrm{~cm}$ carapace width (CW). Estimated starting length (SL) corresponding to the fraction retained was at $8.25 \mathrm{~cm}$ to $13.75 \mathrm{~cm}$. Various researches conducted in the country have come up with values on the length at first maturity for female $P$. pelagicus: 10.5 $\mathrm{cm}$ in Ragay Gulf (Ingles and Braum 1989); $10.6 \mathrm{~cm}$ in 
Table 11. Comparative values of growth parameter from literature and this study obtained for $P$. pelagicus using carapace width (CW) length type

\begin{tabular}{|c|c|c|c|c|c|}
\hline Author/Year & Area & & $\mathrm{L} \infty$ & $\mathbf{k}$ & $\emptyset$ \\
\hline Ingles \& Braum, 1989 & Ragay Gulf, Philippines & & 18.00 & 1.58 & - \\
\hline Germano et.al., 2006 & Eastern Visayas, Philippines & & 8.95 & 1.23 & - \\
\hline \multirow[t]{2}{*}{ Olaño et.al., 2009} & Sorsogon Bay, Philippines & $\mathrm{F}$ & 21.09 & 1.58 & - \\
\hline & & M & 19.39 & 1.58 & \\
\hline Bayate et.al., 2011 & Guimaras Strait, Philippines & & 21.77 & 1.40 & 2.84 \\
\hline Ingles, J., 1996 & Visayan Sea, Philippines & & 22.50 & 0.70 & - \\
\hline Romero, F., 2009 & Visayan Sea, Philippines & & 19.95 & 1.40 & - \\
\hline Mesa et.al., 2012 (this study) & Visayan Sea, Philippines & & 19.10 & 1.55 & 2.75 \\
\hline
\end{tabular}

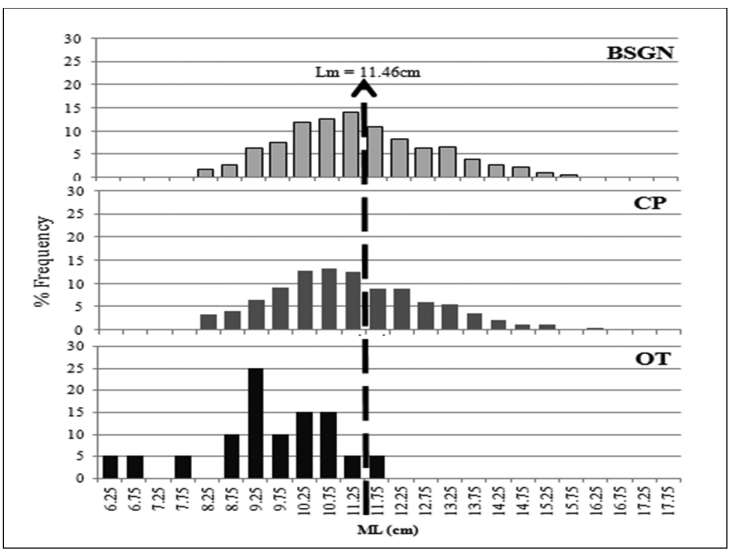

Figure 22. Observed length frequency distribution of $P$. pelagicus caught in Western Visayan Sea by bottomset gillnet (BSGN), crab pot (CP), and otter trawl (OT)

Visayan Sea and Guimaras Strait (Ingles 1996); and $12 \mathrm{~cm}$ in Danajon Bank (Armada et. al. 2009). Fitting the Lm value obtained on the linear relationship between length and weight, corresponding weight at first maturity is $99.83 \mathrm{~g}$ at a correlation coefficient $\left(\mathrm{r}^{2}\right)$ of 0.998 and \pm 1.62 standard deviation.

Length ranges caught by crab gears

Figure 23 shows the length frequency distribution with the superimposed $\mathrm{Lm}$ value for $P$. pelagicus caught by bottom set gillnet, crab pot, and otter trawl. As the figure suggests, all the three gears had a higher percentage of catching the immature sizes shown by the frequencies at the left area of the Lm. Bottom set gillnet catches $57 \%$ immature sizes, $62 \%$ for the crab pot, and $95 \%$ for municipal otter trawl.

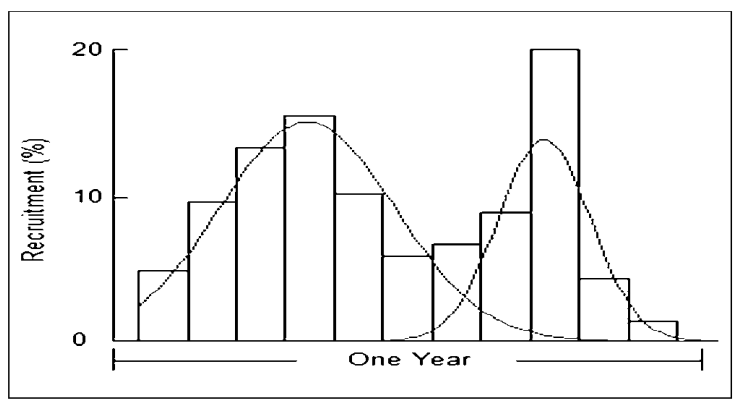

Figure 23 One-year recruitment pulse observed for P. pelagicus caught in Western Visayan Sea

\section{Population parameters}

Growth

Table 11 shows the various growth parameter values of $P$. pelagicus obtained in various fishing grounds in the country. No variation in the values of $L \infty$ is observed considering the time gaps the studies were conducted, in exemption to that of Germano et.al in 2006. For the Visayan Sea, a decreasing value of $\mathrm{L}_{\infty}$ is observed from $22.50 \mathrm{~cm}$ in 1996 to $19.95 \mathrm{~cm}$ in 2009 , and $19.10 \mathrm{~cm}$ in 2012.

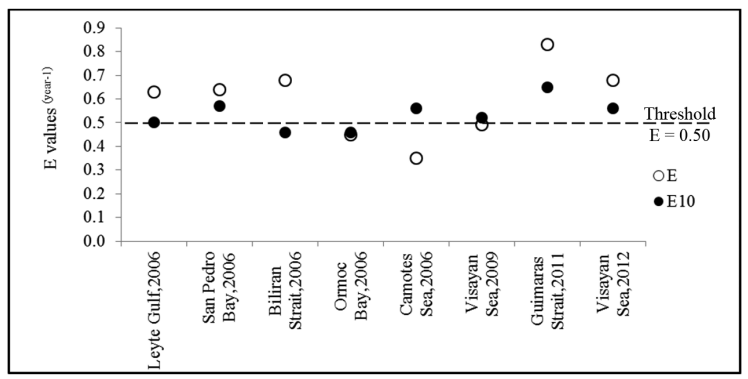

Figure 24. Exploitation rate (E) values from mortalities and optimum exploitation rate (E10) from Beverton \& Holt yield per recruit analysis in comparison to the threshold value of $P$. pelagicus from various biological studies conducted

\section{Recruitment pattern}

The Philippines, located in the tropical region, has multi-fisheries stocks that exhibit a bimodal pattern of recruitment. This means that there are two pulses of stock-recruit from two different cohorts in a year. Recruitment may occur as a weak and strong pulse or an equal pulse of recruit occurring every year.

Using the recruitment pattern routine of the FiSAT II software program, a bimodal pattern with an almost equal pulse is observed for $P$. pelagicus as shown in Figure 24. Major recruitment at the first semester is observed to have its peak in the month of April at $15 \%$. For the second pulse of recruitment at the second semester, the peak is observed in the month of September at $20 \%$. 


\section{Mortalities, Relative Yield and Biomass per Recruit}

As stated in the book of Pauly and Ingles (1984), the optimum fishing mortality in an exploited stock should be approximately equal to natural mortality or optimum exploitation rate that is approximately equal to $0.5^{\text {year-1 }}$. A predominance of estimates of values of $\mathrm{E}>$ 0.5 in a number of stocks should be suggestive of overexploitation.

Figure 25 shows the computed (E), optimum $\left(\mathrm{E}_{10}\right)$, and threshold $(\mathrm{E}=0.5)$ values of exploitation rates in various biological studies conducted for $P$. pelagicus in different fishing grounds of the country. E values from the computed exploitation rates using the software show higher values than that with the threshold at $0.5^{\text {year-1 }}$ except for the Camotes Sea in 2006 (Germano et al. 2006). For this study, computed $\mathrm{E}$ at $0.68^{\text {year-1 }}$ shows a higher value compared with that of the threshold $\mathrm{E}=0.5^{\text {year-1 }}$ at an excess of $36 \%$ and with that of $\mathrm{E}_{10}=0.56^{\text {year-1 }}$ at excess of $21 \%$. Comparing the time series computed E, current data in 2011 for Guimaras Strait and Visayan Sea shows higher values than those from previous studies. This scenario indicates a high fishing exploitation among blue crab resource for Western Visayas.

\section{CON CLUS I ON}

The Blue Swimming Crab Management Plan (BSCMP) is a national initiative involving all stakeholders of the blue swimming crab in the country, from the user to policymakers in the aim of rescuing the dwindling crab industry in the country as well as securing its sustainability over the years. In the implementation of the BSCMP in Western Visayas, this project was materialized to provide more concrete and detailed scientific information to be used as a baseline for policymaking.

Based on the results of this study, overfishing is apparently happening in the crab fishery of Western Visayan Sea. This is shown by the results of the decreasing CPUE over the years. A stabilized CPUE is observed from 1995 to 2011 and 2012 if we use the $\mathrm{kg} /$ day as a unit of measurement. On a more detailed analysis, an apparent decreasing CPUE is observed using gillnetpanel comparing the results in 1995 with that of 2011 and 2012. This is an apparent indication of an increased fishing pressure thru the increase in the length of nets used during operation of crab gillnet gears. The result of the maximum sustainable yield (MSY) showed that the intensity of fishing pressure increases over the years. MSY was achieved prior to 1999 as indicated by the result of Ingles (1998) and with this study thru the increasing gillnet-panels as fishing effort and a decrease in yield over time. This then suggests a $20 \%$ effort reduction of the current year in order to achieve MSY and fMSY.

Growth and recruitment overfishing are observed among $P$. pelagicus stocks for the Western Visayan Sea. Growth overfishing is observed by high value of computed exploitation rate (E) compared to $\mathrm{E}$ $=0.5$ and E10. Another proof is the decreasing $\mathrm{L}_{\infty}$ value from different studies at $22.50 \mathrm{~cm}$ in $1996,19.95 \mathrm{~cm}$ in 2009, and $19.10 \mathrm{~cm}$ in 2012 (this study).

Recruitment overfishing is prevalent as shown by the high percentage of sizes caught before Lm for bottom set gillnet, crab pots, and otter trawlers. Recruitment overfishing is also apparent as a high percentage of sizes prior to $\mathrm{Lm}$ is observed among major crab-catching gears such as bottom set gillnet, crab pot, and otter trawl. Recruitment overfishing is also correlated to the peak of catching season in the months of October and January that coincides with the peak of spawning season of August and January. This scenario indicates that crabs are caught intensely during its spawning season.

\section{RECOMMENDATIONS}

Prior to the implementation of BSCMP under the legal basis of JAO 01-2014, the province of Negros Occidental by virtue of Provincial Ordinance 019 series of 2003, and the province of Iloilo by virtue of Provincial Ordinance 2012-093 series of 2012, had implemented initiatives on the conservation of blue swimming crab stocks. In support of these initiatives, this study recommends the following:

- Reduction of effort on the use of bottom set gillnet or crab entangling net thru the reduction of number of gillnet-panels or reduction of fishing vessels operating thru a systematic licensing system;

- Strict implementation on the banning of otter trawl operation in the municipal waters;

- The use of crab pots should also be regulated by recommending the use of alternate materials such as bamboo, limit the number of pots used per operation, and limit the trap entrance diameter;

- Limit the catching size of crab to $11.5 \mathrm{~cm}$ carapace width (CW); and

- Banning of catching berried crabs and imposing a close season in the months of August to September and January to February.

\section{ACKNOWLED G EM EN T}

The authors would like to express their heartfelt gratitude to the BFAR Management for the funding support to materialize the implementation of the BSC Assessment Project. Gratitude is also given to Prof. Nygiel B. Armada, Fisheries Advisor of the ECOFISH Project, who shared his expertise in the conception of the study plan and details of the data to be collected for a finer scale of analysis made. Acknowledgement of technical support is also given to the National Fisheries Research Development InstituteMarine Fisheries Resource Division (NFRDI- MFRD) management. Above all, heartfelt thank you is due to BFAR-NSAP6 data encoders and field enumerators for their work efficiency, loyalty, and sincerity in the data collection process. To the fisheries staff of the Provincial Government and Municipal Government of Negros Occidental and Iloilo for providing us copies of the local 
ordinances implemented in their local jurisdiction. Salute to all crab fishers, crab picking stations, and crab landing site owners for allowing our field enumerators in the daily catch and effort data collection activities. And to God Almighty for the success of this project.

\section{R E F E R E N C E S}

Abdel Razek FA, Taha SM, Ameran AA. 2006. Population biology of the edible crab Portunus pelagicus (Linnaeus) from Bardawil Lagoon, Northern Sinai, Egypt. Egyptian Journal Of Aquatic Research. Vol. 32 No.1. p. 401-418.

Armada NB., White AT, Christie P. 2009. Managing Fisheries Resources in Danajon Bank, Bohol, Philippines: An Ecosystem-Based Approach to Coastal Management, 37:3, p. 308-330.

Arshad A, Efrizal, Kamarudin MS, Saad CR. 2006. Study on Fecundity, Embryology and Larval Development of Blue Swimming Crab Portunus Pelagicus (Linnaeus, 1758). Research Journal of Fisheries and Hydrobiology, 1(1): 35-44.

BAS (Bureau of Agricultural Statistics). 2004-2006. Statistics of the Philippines Fisheries. Vol. 15. Department of Agriculture- Bureau of Agricultural Statistics. Quezon Avenue, Quezon City. p. 378.

BAS (Bureau of Agricultural Statistics). 2008. Fisheries Statistics of the Philippines 2005-2007. Vol. 16. Department of Agriculture- Bureau of Agricultural Statistics. Quezon Avenue, Quezon City. p. 382.

BAS (Bureau of Agricultural Statistics). 2010. Fisheries Statistics of the Philippines 2007-2009. Vol. 18. Department of Agriculture- Bureau of Agricultural Statistics. Quezon Avenue, Quezon City. p. 394.

BAS (Bureau of Agricultural Statistics). 2012. Fisheries Statistics of the Philippines 2007-2009. Vol. 21. Department of Agriculture- Bureau of Agricultural Statistics. Quezon Avenue

Bayate DEE. 2011. Integrated Management Plan for the Swimming Crab Fishery in the Philippines. Department of Agriculture- Bureau of Fisheries and Aquatic Resources, Regional Field Office 6, Iloilo City. Presented during the BSC Management Plan Consultative Dialogue, Iloilo City, Philippines.

Bayate DEE, Mesa SV, Guanco MR, Doyola MC Jr. 2011. Municipal Fisheries Stock Assessment of Guimaras, Philippines for the Year 2008 to 2010. Proceedings of the 23rd National Research Symposium. Department of Agriculture- Bureau of Agricultural Research, Quezon City. p. 29.

Beverton RJH, Holt SJ. 1957. On the dynamics of exploited fish populations. Fish. Invest., Ministry of Agriculture, Fisheries and Food, London. (2 Sea Fish.), 19: p. 533.

Bjordal A. 2002. The use of technical measures in responsible fisheries: Regulation of fishing gear. In: A fishery manager's guidebook. Cochrane, K.L. (ed.) Management measures and their application. FAO Fisheries Technical Paper. No. 424. Rome, FAO. p. 21-48.

Bolat Y, Bilgin Ş, Günlü A, Izci L, Koca SB, Çetinkaya S, Koca HU. 2010. Chitin-Chitosan yield of freshwater crab (Potamon potamios, olivier 1804) shell. Pakistan Veterinary Journal 30: 5.

Carpenter KE, Niem VH., editors. 1998. FAO species identification guide for fishery purposes. The living marine resources of the Western Central Pacific. Volume 2. Cephalopods, crustaceans, holothurians and sharks. Rome, FAO. 1998. p. 687-1396.

De Lestang S, Hall NG, Potter IC. 2003. Reproductive biology of the blue swimmer crab (Portunus pelagicus, Decapoda: Portunidae) in five bodies of water on the west coast of Australia. Fisheries Bulletin 101: 745-757.

Fisheries Resource Management Project. 2000. Philippine Fisheries Code of 1998 Implementing Rules and Regulations. Department of Agriculture- Bureau of Fisheries and Aquatic Resources, Quezon City, Philippines.

Froese, R. and D. Pauly. (eds) . 2011. FishBase. World Wide Web Electronic Publication. http://www. fishbase.org, version (02/2011).

Gayanilo FC. Jr., Pauly D., editors. 1997. FAO-ICLARM Stock Assessment Tools (FiSAT) Reference Manual. FAO Computerized Information Series (Fisheries) No. 8. Rome, Vol. 2. p. 249.

Germano BP, Melgo JLF, Evangelio JC. 2006. Population, reproductive and fishery biology of blue crab Portunus pelagicus (Linne, 1758) nin Eastern Visayas. Terminal Report, vol. 3. AFMA- Invertebrate Project of Leyte State University (LSU) and the Department of Agriculture - Bureau of Agricultural Research (DA-BAR). p. 116.

Green SJ, Flores JO, Dizon-Corrales JQ, Martinez RT, Nuñal DRM, Armada NB, White AT. 2004. The fisheries of Central Visayas, Philippines: Status and trends. Coastal Resource Management Project of the Department of Environment and Natural Resources and the Bureau of Fisheries and Aquatic Resources of the Department of Agriculture, Cebu City, Philippines. p. 159. 
Ingles JA, Braum E. 1989. Reproduction and larval ecology of the blue swimming crab Portunus pelagicus in Ragay Gulf, Philippines. Int. Gesamt. Hyrodiol. 74: 471-490.

Ingles J.A. 1996. The crab fishery off Bantayan, Cebu, Philippines. Institute of Marine Fisheries and Oceanology. College of Fisheries. University of the Philippines in the Visayas. Miagao, Iloilo. p. 33.

Ingles J.A. 1998. The reproductive qualities of $P$. pelagicus: Optimum criteria of a highly exploited fishery resource: Institute of Marine Fisheries and Oceanology. College of Fisheries. University of the Philippines in the Visayas. Miagao, Iloilo.

Ingles JA, Flores J. 2000. Addressing the ecological impacts of fishing gear: A case study for the blue crab fishery of Guimaras and Visayan Sea. Presented at the 10th JSPS Fisheries Conference, Bogor, Indonesia.

Ingles JA. 2004. Status of the blue crab fisheries in the Philippines, p. 47-52. In DA-BFAR (Department of Agriculture - Bureau of Fisheries and Aquatic Resources). In turbulent seas: The status of Philippine marine fisheries. Coastal Resource Management Project, Cebu City, Philippines. p. 378.

İsmen A. 2002. Maturity and Fecundity of Lizardfish Saurida undosquamis (Richardson, 1848) in Iskenderun Bay Eastern Mediterranean). Tubitak Journal, Turkey. p. 231-237.

Kamrani, Sabili EAN, Yahyavi M. 2010. Stock assessment and reproductive biology of the blue swimming crab, Portunus pelagicus in Bandar Abbas Coastal Waters, Northern Persian Gulf. Journal of the Persian Gulf (Marine Science) 1(2): 11-21.

Nitiratsuwan T, Nitithamyong C, Chiayvareesajja S, Somboonsuke B, 2010. Distribution of Blue Swimming Crab (Portunus pelagicus, Linnaeus 1758) in Trang Province, Thailand. Songklanakarin Journal of Science and Technology 32(2): 207-212.

Pauly D, Ingles J. 1984. An Atlas of the Growth, Mortality, and Recruitment of the Philippine Fishes. Institute of Marine Fisheries Development and Research, College of Fisheries, University of the Philippines, Diliman, Quezon City. International Center for Living Aquatic Resources Management. Manila, Philippines. p. 1-8.

Province of Iloilo. 2012. Provincial Ordinance No. 2012-093: "Prohibition on the catching of berried and undersized crabs". Office of the Provincial Government of Iloilo, Iloilo City.

Province of Negros Occidental. 2003. Provincial Ordinance No. 019:"An ordinance regulating the catching, selling, possessing or buying of gravid blue crabs and crablets in the Province of Negros Occidental". Office of the Provincial Government of Negros Occidental, Bacolod City.

Rasalan SB. 1957. Marine Fisheries of Central Visayas. Philippine Journal of Fisheries. 5(1): 53-89.

Romero FG. 2009. Population Structure of the Blue Crabs, Portunus pelagicus (L.) in the Visayan Sea: Implications to Fisheries Management. Ph.D. dissertation. University of the Philippines, Diliman, Philippines.

Ruangsivakul N, Prajakjitt P, Dickson JO, Siriraksophon S. 2003. Fishing gear and methods in Southeast Asia: III. Philippines, Part 1. Southeast Asian Fisheries Development Center, Training Department, Samut Prakan, Thailand. p. 189-192.

SEAFISH. 2005. Basic fishing method. Fisheries Development Center. SEAFISH Flume Tank, Manchester Street, United Kingdom. p. 41.

SEAFDEC (Southeast Asian Fisheries Development Center). 1998. Fishing gear and methods in Southeast Asia: Thailand (Revisional Edition). SEAFDEC-Training Department, Samut Prakan, Thailand. p. 390.

Sheung-Ping W, Chi-Lu S, Su-Zan Y. 2003. Sex Ratio and Sexual Maturity of Swordfish Xiphias gladius, Linn. In waters of Taiwan. Zoological Studies 42(4): 529539.2003 .

Smith, K. D., N.G. Hall, S. de Lestang, and I.C.Potter. 2004. Potential bias in estimates of the size of maturity of crabs derived from trap samples. ICES Journal of Marine Science 61: 906-912.

Smith GS, Sumpton WD. 1989. Behavior of Commercial Sand Crab Portunus pelagicus (L.) at Trap Entrances. Asian Fisheries Science 3:101-113.

Sokumaran KK, Neelakantan B. 1999. Spawning Biology of Two Marine Portunid Crabs, Portunus (Portunus) sanguinolentus (Herbst) and Portunus (Portunus) pelagicus (Linnaeus) from the Karnataka Coast. The Fourth Indian Fisheries Forum Proceeding. 24-28 November 1996. Kochi. p. 35-38.

Soundarapandia P, Tamizhazhagan T. 2009. Embryonic Development of Commercially Imporatant Swimming Crab Portunus pelagicus (Linnaeus). Journal of Biological Sciences 1(3):106-108.

Sparre P, Venema C. 1992. Introduction to tropical fish stock assessment. Part I- Manual. FAO-Fisheries technical paper. No. 306.1, Rev.1, FAO.1992. p. 376. 
Sudhakar M, Manivannan K, Soundrapandian P. 2009. Nutritive Value of Hard and Soft Shell Crabs of Portunus sanguinolentus (Herbst). International Journal of Animal and Veterinary Advances 1(2): 44-48.

Sumpton WD, Potter MA, Smith GS. 1994. Reproduction and Growth of the Commercial Sand Crab, Portunus pelagicus (L.) in Moreton Bay, Queensland. Asian Fisheries Science 7. Asian Fisheries Society, Manila, Philippines. p. 103-113.
Svane I, Hooper GE. 2004. Blue Crab (Portunus pelagicus) Fishery. Fishery Assessment Report to PIRSA for the Blue Crab Management Committee. South Australian Research and Development Institute (Aquatic Science), Adelaide. RD 03/0274-2.

Williams MJ, Primavera JH. 2001. Choosing tropical Portunid species for culture, domestication, and stock enhancement in the Indo-Pacific. Asian Fisheries Society, Manila, Philippines. Asian Fisheries Science 14: 121-142 